

\title{
LICENCIAMENTO AMBIENTAL DE UM CEMITERIO PARQUE NO MUNICÍPIO DE FRANCISCO BELTRÃO-PR
}

Fabio Antoninho Gambin ${ }^{1,2}$, Valter Antonio Becegato ${ }^{3}$, Nádia Sanzovo ${ }^{4}$, William César Polônio Machado ${ }^{4}$, Gabriela Salami ${ }^{5}$

(1-Extraído da monografia do primeiro autor do curso de Especialização em Gestão Ambiental em Municípios da Universidade Tecnológica Federal do Paraná, Unidade Sudoeste, Campus de Pato Branco-PR; 2-Consultor - Engenheiro químico: E-mail: fabiogambin@yahoo.com.br; 3-Professor da Universidade do Estado de Santa CatarinaUDESC Lages-SC, E-mail: becegato@cav.udesc.br; 4-Professor da UTFPR: E-mail: sanzovo@brturbo.com.br; wcpm@mail.crea-pr.org.br; 5-Acadêmica do curso de Engenharia Florestal UDESC-Lages-SC: E-mail:florestalgabi_cav@yahoo.com.br).

\section{Resumo}

Este trabalho trata acerca do licenciamento ambiental de um cemitério parque do município de Francisco Beltrão-PR, desde a revisão das leis pertinentes ao tema, até a elaboração de projetos, preenchimento de formulários e protocolar o pedido de Licença de Operação junto ao IAP - Instituto Ambiental do Paraná. Por intermédio deste estudo, procurou-se caracterizar a área aonde funciona o cemitério e os processos de degradação biológica que ocorrem aos corpos sepultados com as inevitáveis inter-relações com o meio ambiente e, desta forma, executar as ações necessárias para o correto funcionamento do cemitério, como a construção de poços de monitoramento do lençol freático para detecção de resíduos (chorume), assim como estabelecer um Plano de Controle Ambiental, aonde consta todas as recomendações quanto ao destino adequado dos resíduos e efluentes produzidos.

Palavras-chaves: Cemitério Parque, licenciamento ambiental, monitoramento de água.

\section{Abstract \\ ENVIRONMENTAL LICENSING OF A CEMETERY PARK IN THE CITY OF THE FRANCISCO BELTRÃO-PR}

This work treats about the environmental license of a cemetery park in Francisco Beltrão-PR, from the review of the pertinent laws that concerns the subject to the elaboration of projects,

\footnotetext{
- Recebido para publicação em 08 de Dezembro de 2007; Aprovado para publicação em 23 de Abril de 2008
} 


\section{GEOAMBIENTE ON-LINE \\ Revista Eletrônica do Curso de Geografia do Campus Jataí - UFG \\ www.jatai.ufg.br/geografia \\ | Jataí-GO | N.10 | jan-jun/2008

filling of forms and registration of the Operation License request next to IAP - Instituto Ambiental do Paraná. Through this study, it has been aimed to characterize the area where the cemetery locates and the trials of biological degradation that occur to the buried bodies with the inevitable inter-relations with the environment and, in this way, to perform the necessary actions for the correct operation of the cemetery, as the construction of monitoring wells of the water table for detection or residues, as well as to establish an Environmental Control Plan, which are all the recommendations regarding the suitable destiny of the residues and produced effluents.

Key words: Cemetery Park, Environmental license, Monitoring of water

\section{Introdução}

De acordo com uma política ambiental que objetiva preservar o solo e os recursos hídricos superficiais e subterrâneos, ressalta-se a necessidade de licenciamento ambiental de atividades potencialmente poluidoras.

Este assunto tem gerado controvérsias não só no Brasil, mas em vários outros países. Uma peculiaridade dos cemitérios em relação a outras atividades urbanas potencialmente impactantes é que o sepultamento tem conotações culturais e religiosas diversas que devem ser respeitadas, o que tem dificultado a adoção de um padrão único por parte dos órgãos governamentais (BARBOSA \& COELHO, 2006).

Os cemitérios, por sua vez, envolvem uma problemática intrinsecamente vinculada à saúde pública e ambiental, dado o comprometimento potencial a que estão sujeitos os solos e, principalmente, as águas que são utilizadas para o abastecimento público.

Ainda existem muitas dúvidas sobre o impacto efetivo de cemitérios sobre o ambiente, o risco para a população vizinha e as restrições e cuidados que podem ser exigidos para o seu controle. (MATOS, 2006)

Dada a dimensão da área normalmente ocupada para construção de cemitérios, o tempo médio de existência desse tipo de instalação e a imensa complexidade desse sistema, a definição de pré-alvos e alvos para investigação de contaminações de solos e águas subterrâneas dentro dessas unidades com critérios estritamente objetivos é ação bastante complexa.

No intuito de contribuir com o processo de definição de mecanismos objetivos de avaliação, propôs-se aqui uma estratégia baseada numa análise dos diversos constituintes 


\section{GEOAMBIENTE ON-LINE \\ Revista Eletrônica do Curso de Geografia do Campus Jataí - UFG \\ www.jatai.ufg.br/geografia \\ | Jataí-GO | N.10 | jan-jun/2008

operacionais dos parâmetros e da legislação relacionados, remontando-os depois de analisados para a obtenção do quadro final para a execução da obra.

\section{Material e Métodos}

\subsection{Caracterização da área de estudos}

A caracterização hidrogeológica com a definição de fluxo das águas subterrâneas e a identificação das águas de recarga, torna-se indispensável para a instalação de um cemitério parque.

O padrão de fraturamento das rochas basálticas do Planalto de Guarapuava, do qual faz parte a região sudoeste do Paraná, funciona como verdadeiro canal alimentador de aqüíferos subterrâneos, necessitando medidas de monitoramento da descarga de efluentes químicos, biológicos e industriais para evitar a contaminação das águas subterrâneas (SANTOS FILHO, 2006).

A área de estudo é o Cemitério Parque Jardim da Luz localizado na porção noroeste da cidade de Francisco Beltrão (coordenadas geográficas com latitude de $26^{\circ} 03$ ' 38,3' S, longitude de 53 $03^{\prime}$ 49,8', WO, com aproximada elevação de 687 metros (Figuras 1 e 2).

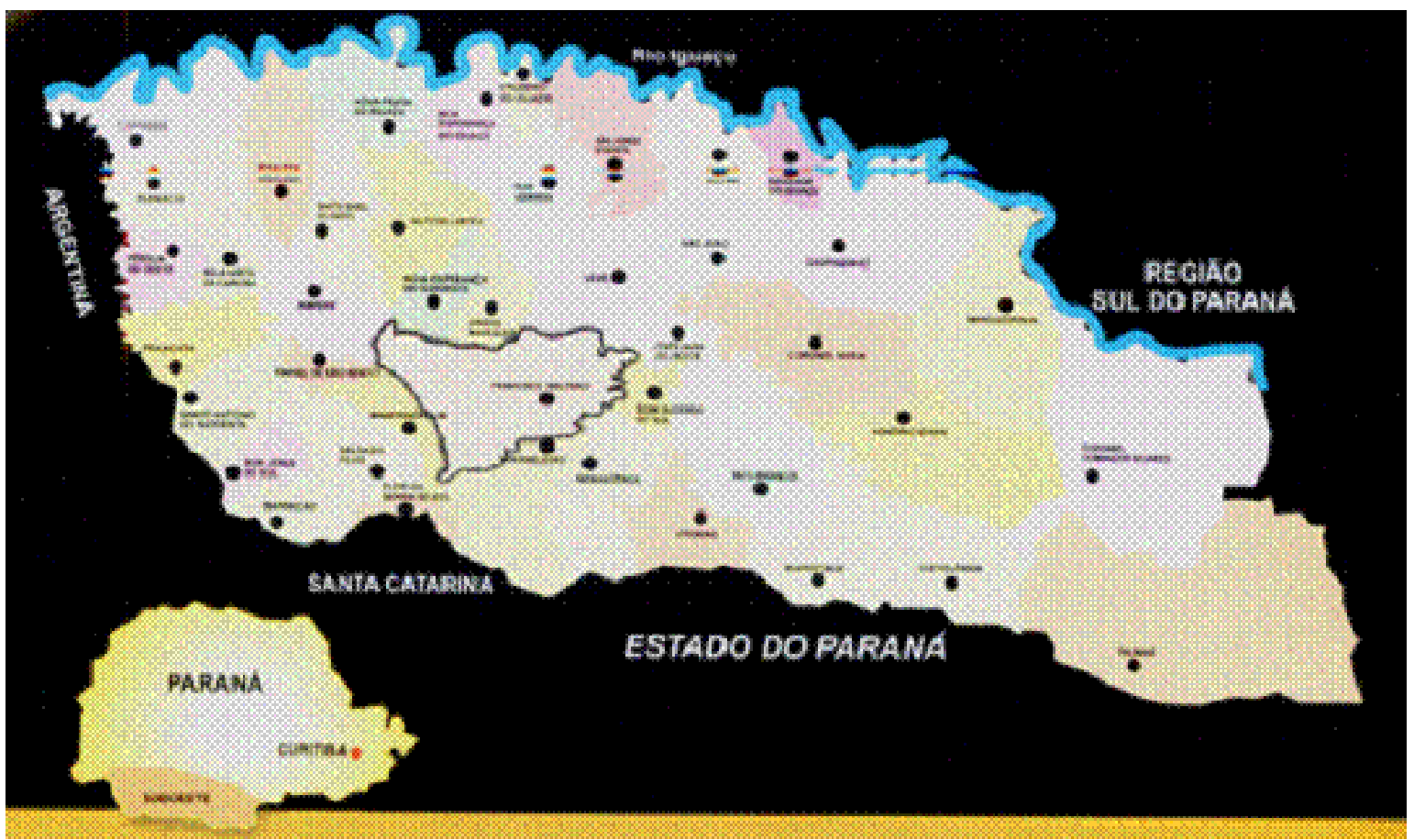

Figura 1 - Mapa de localização do Sudoeste do Paraná e do município de Francisco Beltrão Fonte: LUZ, (2006) 


\section{GEOAMBIENTE ON-LINE}

Revista Eletrônica do Curso de Geografia do Campus Jataí - UFG www.jatai.ufg.br/geografia

| Jataí-GO | N.10 | jan-jun/2008

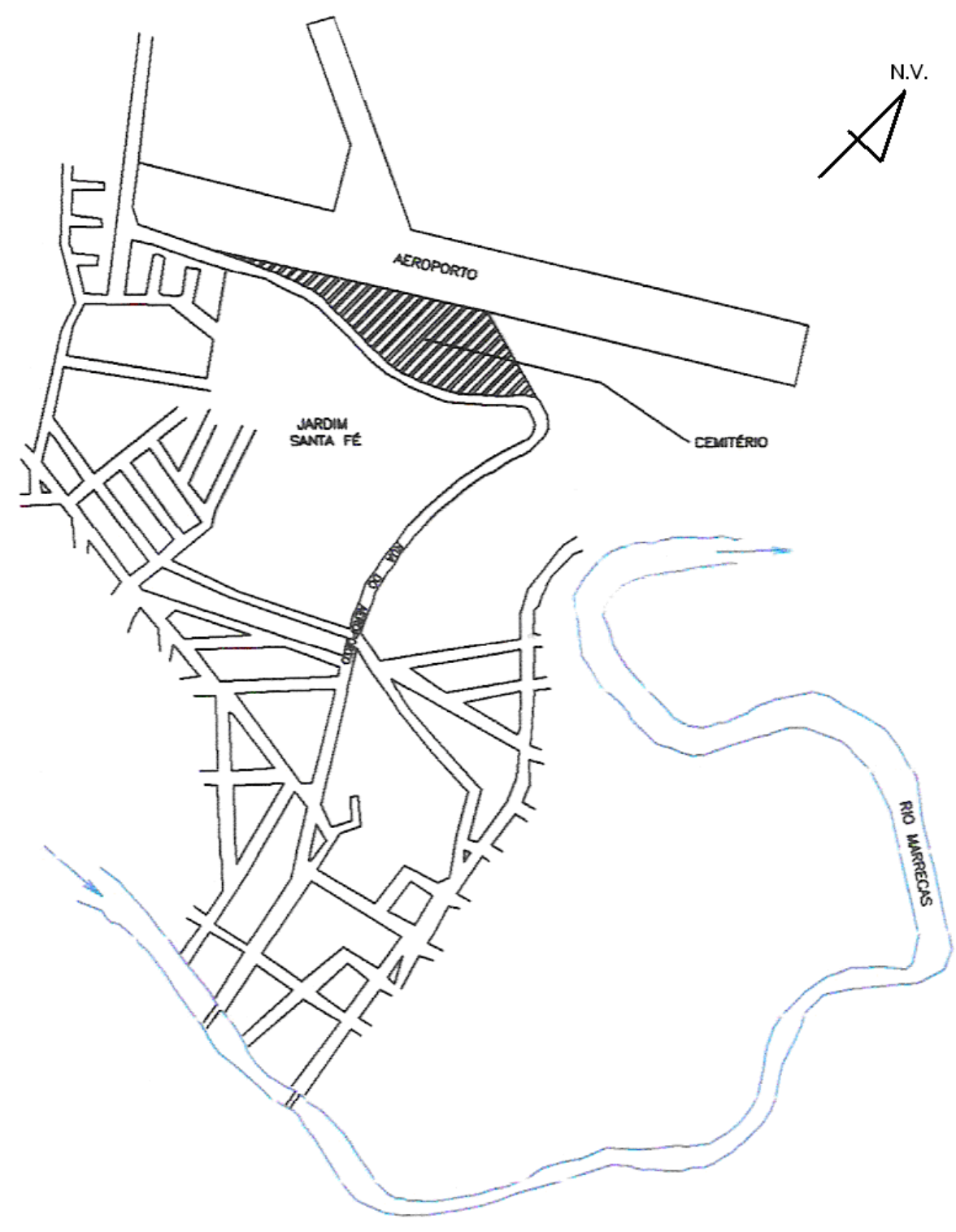

Figura 2 - Croqui de localização do empreendimento

O Empreendimento encontra-se situada a cerca de $800 \mathrm{~m}$ do rio Marrecas e a $30 \mathrm{Km}$ do rio Chopim, ambos pertencentes à bacia hidrográfica do rio Iguaçu. O terreno possui uma área total de $42.089 \mathrm{~m}^{2}$, da qual é prevista uma ocupação de $30.000 \mathrm{~m}^{2}$. Nas Figuras 3 e 4 pode-se visualizar o empreendimento. 


\section{GEOAMBIENTE ON-LINE}

Revista Eletrônica do Curso de Geografia do Campus Jataí - UFG www.jatai.ufg.br/geografia

| Jataí-GO | N.10 | jan-jun/2008



Figura 3 - Entrada do cemitério



Figura 4 - Vista geral do cemitério 


\section{GEOAMBIENTE ON-LINE \\ Revista Eletrônica do Curso de Geografia do Campus Jataí - UFG \\ www.jatai.ufg.br/geografia \\ | Jataí-GO | N.10 | jan-jun/2008

Apesar de se encontrar muito próximo do perímetro urbano a área está inserida na zona rural numa das partes mais altas do município não estando suscetível às cheias em decorrência da abundância de chuvas. Antes da instalação do cemitério, o terreno nunca foi utilizado para moradia, comércio ou indústria, sendo desmatado ao longo do tempo para utilização comercial da madeira. O solo é revestido em sua quase totalidade por vegetação rasteira e a sua vizinhança compreende algumas residências familiares e o aeroporto municipal.

\section{2 - Cemitérios: Impacto ambiental}

Os cemitérios envolvem uma problemática intrinsecamente vinculada à saúde pública e ambiental, dado o comprometimento potencial a que estão sujeitos os solos e as águas locais, utilizadas para o abastecimento público.

Outra característica que se evidencia em âmbitos nacional e externo, é a carência de dados de monitoramento em quantidade e diversidade suficientes para uma análise mais conclusiva, o que alimenta a polêmica sobre as restrições impostas pela legislação ao setor (BARBOSA \& COELHO, 2006).

Os estudos relativos a cemitérios e meio ambiente, embora considerados relativamente escassos e incipientes (Matos, 2001), não parecem ser motivo de preocupação recente entre os pesquisadores. Mulder (1954 apud ESPINDULA, 2004) relata a alta incidência de febre tifóide no período de 1863-1867, relacionada ao consumo de água subterrânea por pessoas que viviam nas proximidades da cidade de Berlim. O mesmo autor menciona a captação de água com sabor adocicado e odor desagradável, sem referir o período de ocorrência, em poços localizados próximos a cemitérios na cidade de Paris, principalmente na época do verão.

Estudo conduzido por Schraps (1972, apud ESPINDULA, 2004) em um cemitério implantado em terreno aluvionar da Alemanha Ocidental, onde foi constatado através de análises químicas e bacteriológicas da água subterrânea, o risco efetivo dessa fonte contaminante, sobretudo a pequenas distâncias dos túmulos (0,5 a 2,5 metros), mas rapidamente atenuado com o aumento dessas distâncias (Tabela 1). 


\section{GEOAMBIENTE ON-LINE \\ Revista Eletrônica do Curso de Geografia do Campus Jataí - UFG \\ www.jatai.ufg.br/geografia \\ | Jataí-GO | N.10 | jan-jun/2008 \\ IEEO \\ EAMBIENTE \\ ISSN 1679-9860}

Tabela 1 - Qualidade da água subterrânea em relação à distância dos túmulos e os pontos de amostragem.

\begin{tabular}{|c|c|c|c|c|c|c|c|}
\hline \multirow{2}{*}{ Parâmetros avaliados } & \multicolumn{7}{|c|}{ Distância dos túmulos (m) } \\
\cline { 2 - 8 } & 0,5 & 1,5 & 2,5 & 3,5 & 4,5 & \multicolumn{2}{c|}{5,5} \\
\hline Contagem de bactérias (UFC/ml) & 8.000 & 8.000 & 6.000 & 3.600 & 1.200 & 180 \\
\hline $\mathrm{NH}_{4}(\mathrm{mg} / \mathrm{l})$ & 6 & 0,75 & - & - & - & - \\
\hline $\mathrm{NO}_{3}(\mathrm{mg} / \mathrm{l})$ & 4,8 & 0,1 & - & - & - & - \\
\hline $\mathrm{DQO}(\mathrm{mg} / \mathrm{l})$ & 26,7 & 16,4 & 15,4 & 15,4 & 11,4 & 11,4 \\
\hline
\end{tabular}

Fonte: Schraps, (1972 apud Espíndula, 2004).

Os cemitérios quando implantados sem consideração dos aspectos técnicos necessários à proteção das águas subterrâneas, especificamente as do aqüífero freático, poderão causar impactos ao meio ambiente, como a contaminação dessas águas em decorrência do processo de decomposição dos corpos, quando prolifera uma infinidade de microrganismos. A esse processo, somam-se a permeabilidade dos terrenos, a ocorrência de períodos de maior precipitação pluviométrica, que propiciam o transporte desses microrganismos e a elevação do nível freático do aquíifero, podendo expor suas águas ao contato direto com as sepulturas ou com camadas contaminadas do solo (ESPINDULA, 2004).

Os mortos são capazes de se tornar perigosos poluentes através do processo de decomposição de um corpo, que ao todo leva em média dois anos e meio, gerando um líquido chamado necrochorume. Este composto é eliminado durante o primeiro ano após o sepultamento. Trata-se de um escoamento viscoso, com a coloração acinzentada que com a chuva pode atingir o aqüífero freático, ou seja, a água subterrânea de pequena profundidade.

O cadáver de um adulto pesando em média 70 quilos produz cerca de 30 litros de necrochorume em seu processo de decomposição. Esse líquido é composto por $60 \%$ de água, $30 \%$ de sais minerais e 10\% de substâncias orgânicas, duas delas altamente tóxicas: a putresina e a cadaverina (ACKERMANN, 2001).

O impacto potencial dos cemitérios horizontais é decorrente da produção de gases $\left(\mathrm{CO}_{2}, \mathrm{NH}_{3}\right.$, alguns compostos voláteis como as diaminas) e do produto de coliqüação, que é um líquido viscoso, pouco mais denso do que a água, contendo os subprodutos químicos e biológicos liberados durante a decomposição do corpo humano. Além destes, podem contribuir também a degradação, com o tempo, dos materiais usados nas urnas, embalsamamento, limpeza e manutenção dos jazigos, e patógenos associados a eventuais mortes por doenças infecto-contagiosas. (BARBOSA \& COELHO, 2006) 


\section{GEOAMBIENTE ON-LINE \\ Revista Eletrônica do Curso de Geografia do Campus Jataí - UFG \\ www.jatai.ufg.br/geografia \\ | Jataí-GO | N.10 | jan-jun/2008

Os vírus não têm autonomia biológica para a sobrevivência, dependendo de um hospedeiro, diferentemente das bactérias e dos fungos. Assim, o único meio de transporte de um vírus isolado através do solo seria "advectivo", quando carreado pela água em movimento pelos poros. E o seu avanço é altamente dependente da condição de sobrevivência durante o tempo de residência no solo.

Ainda segundo Barbosa e Coelho (2006), para os microrganismos, os processos mais importantes de retenção e transformação no solo são:

Mortalidade (die-off) - se as condições ambientais forem desfavoráveis à sobrevivência do microrganismo, sua população decai rapidamente com o tempo. Este decaimento é importante para todos os microrganismos;

Filtração mecânica - este mecanismo representa a retenção física dos microrganismos nos poros do solo, sendo mais relevante para as bactérias do que para os vírus, e tanto maior quanto menor a dimensão média dos poros efetivos;

Adsorção - mesmo mecanismo descrito para as espécies químicas, em que forças eletrostáticas atraem os microrganismos para a superfície das partículas minerais, sobretudo argila, ou de matéria orgânica. Principal mecanismo de retenção dos vírus no solo, mas pode ser reversível;

Adsorção / Adesão - processo característico das bactérias, em que os microrganismos aderem à superfície das partículas por mecanismos físico-químicos.

Barbosa e Coelho (2006) afirmam que os dois principais mecanismos de transporte e migração de espécies químicas através de meios porosos como os solos são:

A advecção, em que a espécie é arrastada pelo meio em movimento (água ou ar);

A difusão molecular, em que a espécie migra do ponto de maior concentração para o de menor concentração.

No caso das espécies químicas, os principais mecanismos de retenção e transformação na matriz do solo são:

Adsorção pelas partículas de argila, óxidos e hidróxidos livres e matéria orgânica;

> Reações químicas como oxidação/redução, reações ácido-base, precipitação, complexação pela matéria orgânica e outras menos importantes;

Degradação pelos microrganismos, no caso de compostos orgânicos.

Barbosa e Coelho (2006) relatam que os indicadores químicos e biológicos mais importantes para o monitoramento de cemitérios através de análises de amostras de água, são: 


\begin{tabular}{|c|c|}
\hline $\begin{array}{r}\text { GEOAMBIENTE ON-LINE } \\
\text { Revista Eletrônica do Curso de Geografia do Campus Jataí - UFG } \\
\text { www.jatai.ufg.br/geografia } \\
\text { | Jataí-Go | N.10 | jan-jun/2008 | }\end{array}$ & 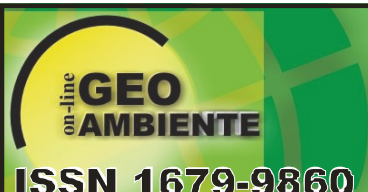 \\
\hline
\end{tabular}

$>\mathrm{pH}$ (em geral observa-se uma tendência de aumento);

$>$ Condutividade elétrica específica - CEE (aumento devido à presença de sais na solução);

Ílons: $\mathrm{Cl}^{-}$, carbonatos $\left(\mathrm{HCO}_{3}{ }^{-} ; \mathrm{CO}_{3}{ }^{\circ}\right), \mathrm{Ca}^{2+}$;

Nitrogênio (N) e Fósforo (P) (monitoramentos não detectaram aumento nestes parâmetros);

Dureza (ou Alcalinidade) (observado aumento);

Alguns metais pesados, em particular ferro, Cromo total (não analisados);

DQO (Demanda Química de Oxigênio), $\mathrm{DBO}_{5}$ (Demanda Bioquímica de Oxigênio);

$>$ Carbono Orgânico Total (COT) (como parâmetro indicador de compostos orgânicos);

Bactérias heterotróficas (todos observaram aumento);

> Bactérias proteolíticas (todos que analisaram encontraram presença significativa);

$>$ Bactérias lipolíticas (idem);

$>$ Clostrídios sulfito-redutores (idem);

$>$ Coliformes Totais (presentes em todos, porém maiores valores em locais sem saneamento);

Coliformes Fecais (presentes em parte das amostras, também maiores valores em locais sem saneamento).

Os gases constituem emissões atmosféricas de pequena magnitude na área dos sepultamentos (ACKERMANN, 2001).

O produto de coliqüação por ser viscoso não percola facilmente através do carneiro de concreto armado e do solo, a menos que seja diluído pela água. Neste caso os seus constituintes químicos e microbiológicos podem ser transportados para o solo circundante, eventualmente atingindo os sistemas de drenagem e o lençol freático. Sob o aspecto da contaminação química, os efeitos mais prováveis são um aumento na presença de compostos de nitrogênio e fósforo, na concentração de sais minerais $\left(\mathrm{Cl}^{-}, \mathrm{HCO}_{3}{ }^{2}, \mathrm{Ca}^{+2}, \mathrm{Na}^{+}\right)$, e conseqüentemente na condutividade elétrica, no $\mathrm{pH}$ e na alcalinidade e dureza da solução do solo. Devem ser liberados também compostos orgânicos diversos produzidos no processo de decomposição, degradáveis, e que por esta razão devem causar um aumento da atividade microbiana no solo sob a área de sepultamentos. 


\section{GEOAMBIENTE ON-LINE \\ Revista Eletrônica do Curso de Geografia do Campus Jataí - UFG \\ www.jatai.ufg.br/geografia \\ | Jataí-GO | N.10 | jan-jun/2008

No Brasil não é usual a prática do embalsamamento, exceto em algumas situações particulares. Nesses casos é utilizado o processo em que se usa o formol. Quanto à potencial liberação para o solo do formaldeído utilizado para embalsamar os corpos, como este composto é altamente volátil e apresenta uma degradação rápida na presença de matéria orgânica, sua presença deve ficar restrita ao redor da sepultura. (BARBOSA e COELHO, 2006)

As maiores incidências de microorganismos foram encontradas em cemitérios públicos localizados em centros urbanos e vizinhos a favelas e a corpos d'água contaminados por esgoto (MATOS, 2001).

\section{3 - Legislação}

\subsubsection{Lei Estadual $n^{\circ} 10.233$ de 28 de dezembro de 1992}

Institui a Taxa Ambiental devida por ocasião do requerimento de licenciamento, a sua base de cálculo, casos de isenções e o destino dessa arrecadação.

\subsubsection{Resolução CONAMA $n^{\circ} 5$ de 5 de agosto de 1993}

Discorre sobre a necessidade de normas para o tratamento de resíduos sólidos oriundos de serviços de saúde, portos e aeroportos, bem como a necessidade de estender tais exigências aos terminais ferroviários e rodoviários, com vistas a preservar a saúde pública e a qualidade do meio ambiente.

\subsubsection{Resolução CONAMA n ${ }^{\circ} 237$ de 19 de dezembro de 1997}

Dispõe sobre a necessidade de licenciamento ambiental como instrumento de gestão ambiental, instituído pela Política Nacional do Meio Ambiente. Define Licenciamento Ambiental, Licença Ambiental, Estudos Ambientais e Impacto Ambiental Regional. Orienta quanto aos empreendimentos que estão sujeitos ao licenciamento ambiental assim como os órgãos responsáveis pelos licenciamentos. Define os três tipos de licenças: Licença Prévia (LP), Licença de Instalação (LI) e Licença de Operação (LO). Os documentos exigidos e o trâmite necessário ao processo de licenciamento além da validade de cada licença. 


\section{GEOAMBIENTE ON-LINE \\ Revista Eletrônica do Curso de Geografia do Campus Jataí - UFG \\ www.jatai.ufg.br/geografia \\ | Jataí-GO | N.10 | jan-jun/2008

Dispõe sobre o licenciamento ambiental de cemitérios: Os documentos e medidas necessárias como sondagem mecânica do terreno, estudo demonstrando o nível máximo do lençol freático e levantamento topográfico planialtimétrico. Os locais proibidos para instalação de cemitérios como em área de preservação permanente, terrenos cársticos, área de manancial para abastecimento humano e outros. A distância mínima do fundo das sepulturas para com o lençol freático. Questões técnicas como a necessidade de troca gasosa de maneira a permitir a adequada decomposição dos corpos. O destino de resíduos sólidos não humanos. Casos em que o processo de licenciamento é simplificado. Define de que forma a área do cemitério será ocupada quando da desativação da atividade de sepultamentos, além da necessidade de requerer licença para tal ação.

\subsubsection{Decreto Estadual $n^{\circ} 3320$ de 12 de julho de 2004}

Aprova os critérios, normas, procedimentos e conceitos aplicáveis ao SISLEG Sistema de manutenção, recuperação e proteção da reserva florestal legal e áreas de preservação permanente e dá outras providências.

Toda propriedade rural deverá destinar $20 \%$ de sua área como reserva legal e deverá estar averbada na escritura. No presente caso, o cemitério se encontra em área rural, porém não existe área verde suficiente para tal destino, sendo assim, o proprietário do terreno adquiriu uma outra propriedade para funcionar como reserva legal do terreno aonde funciona o cemitério.

\subsubsection{Resolução da Diretoria Colegiada ANVISA n $n^{\circ} 306$ de 7 de dezembro de 2004}

Dispõe sobre o regulamento técnico para o gerenciamento de resíduos de serviços de saúde, com vistas a preservar a saúde pública e a qualidade do meio ambiente, sua abrangência, a necessidade de um Plano de Gerenciamento de Resíduos, abordando a forma de manejo do resíduos, segregação, acondicionamento e tratamento. A identificação e separação dos resíduos em grupos A, B, C, D, E.

\subsubsection{Resolução Estadual n ${ }^{\circ}$ 019/04 - SEMA}

Estabelece requisitos e condições técnicas para a implantação de cemitérios destinados ao sepultamento, no que tange à proteção e à preservação do ambiente, em particular do solo e das águas subterrâneas. A necessidade de EPIA - Estudo Prévio de Impacto Ambiental. A 


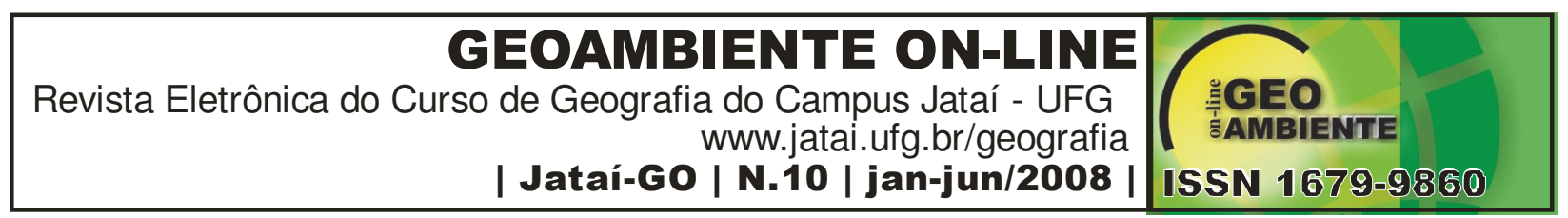

necessidade de licença para encerramento das atividades. Casos em que o processo de licenciamento ambiental é simplificado. Os requisitos mínimos que os cemitérios deverão atender quando da solicitação de Licença Ambiental, quais sejam:

- Sistema de drenagem superficial adequado e eficiente;

- A presença de uma cerca viva com largura mínima de 5 metros ao redor do cemitério;

- Solo com coeficiente de permeabilidade entre $10^{-4}$ e $10^{-6} \mathrm{~cm} / \mathrm{s}$;

- Distância mínima de 1,5 m acima do mais alto nível do lençol freático;

- Tratamento adequado dos resíduos sólidos relacionados à exumação dos corpos;

- Presença de poços de monitoramento de água;

- Columbários para entumulamento de cadáveres impermeabilizados e

- Sistema de controle de poluição atmosférica oriundo dos gases cadavéricos.

\subsubsection{Resolução CONAMA $n^{o} 368$ de 28 de março de 2006}

Altera dispositivos da Resolução $n^{0} 335$ de 3 de abril de 2003, que dispõe sobre o licenciamento ambiental de cemitérios, nos artigos 3 e 5 .

Em seu artigo 3, não restringe-se mais a presença de cemitérios em área de manancial para abastecimento humano.

No artigo 5, acrescenta-se que a medição do nível do lençol freático deverá ser medido no período final da estação de cheias. Para os cemitérios horizontais, em áreas de manancial para abastecimento humano, deverão ser atendidas, além das exigências mencionadas, outras como:

Área de implantação do cemitério numa distância segura de corpos de água;

Sistema de drenagem superficial adequado e eficiente;

Solo com coeficiente de permeabilidade entre $10^{-5}$ e $10^{-7} \mathrm{~cm} / \mathrm{s}$. 


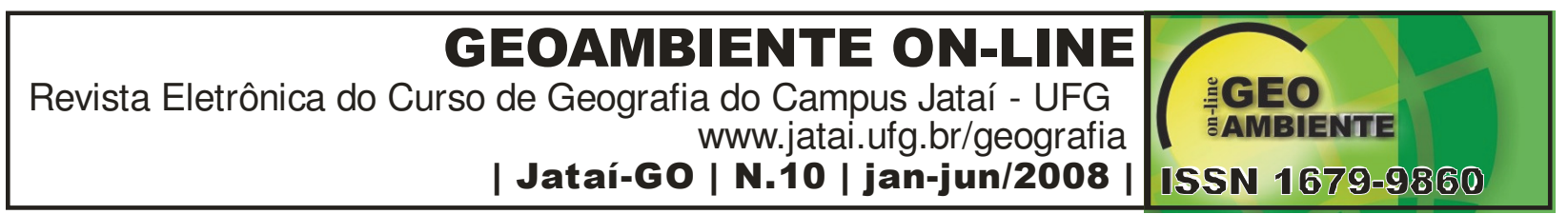

\section{Resultados e Discussão}

\section{1 - Plano de Controle Ambiental}

O cemitério em questão está em operação há 8 anos com 450 jazigos implantados, afastado de adensamentos populacionais, indústrias e etc. $\mathrm{P}$

Em visitas ao entorno imediato da região do cemitério, não foi constatado a presença de poços rasos de água para sedentação humana.

O rio mais próximo do empreendimento é o Rio Marrecas, localizado a cerca de 800 metros de distância da área objeto de estudo.

Em seu histórico de operação, nunca houve problemas com contaminação de solo, corpos hídricos e ar.

Diariamente os funcionários trabalham na manutenção do cemitério, aparando as gramas, recolhendo flores, vasos e coroas que sofreram a ação das intempéries climáticas.

A água a ser utilizada no empreendimento somente se refere ao consumo humano, utilizada nos vasos sanitários dos banheiros do cemitério, e é obtida através de uma vertente.

\section{2 - Resíduos do cemitério}

\subsection{1 - Efluentes líquidos}

As águas pluviais que incidem na cobertura das edificações são coletadas através de calhas e posteriormente lançadas em tubulações específicas que as conduzam para fora da área ocupada. As que caem diretamente no solo, sofrem absorção do mesmo, ou escoam para as galerias de águas pluviais.

\subsection{2 - Esgotos sanitários}

Os esgotos sanitários são encaminhados a uma fossa séptica/sumidouro. Existem 3 banheiros no empreendimento. É difícil dizer a quantidade de efluentes sanitários pela incerteza da quantidade de pessoas que transitam diariamente no cemitério. Assumindo um consumo de água de 25 litros por pessoa e estimando que, em média, 20 pessoas / dia visitem o cemitério; acarretará uma quantidade de 500 L / dia de efluentes sanitários com carga orgânica de 300 mg/l. 


\section{GEOAMBIENTE ON-LINE \\ Revista Eletrônica do Curso de Geografia do Campus Jataí - UFG \\ www.jatai.ufg.br/geografia \\ | Jataí-GO | N.10 | jan-jun/2008

\subsection{3- Efluentes líquidos originados do processo de decomposição dos corpos}

O jazigo, aonde permanece o caixão, é impermeabilizado, não havendo possibilidade de escoamento do necrochorume para o solo. Existem pequeníssimas frestas a cerca de $80 \mathrm{~cm}$ de profundidade por onde passam os gases originados do processo de decomposição; o solo, então, funciona como filtro desses gases, e não há o problema de pressurização do jazigo.

A forma de encaixe das placas de concreto (caracterizando o jazigo), dispondo as frestas, faz com que haja o transporte dos gases para fora do jazigo, porém não deixa a umidade do solo penetrar no seu interior. Conforme dito anteriormente, um adulto produz cerca de 30 Litros de necrochorume, e, esse montante permanece totalmente dentro do jazigo.

Atualmente os caixões são feitos com uma camada de maravalha e serragem para absorver essa matéria orgânica, inviabilizando qualquer tentativa de fuga para o solo. Somente depois de cinco anos, existe a possibilidade de exumação de cadáveres. Em recentes exumações foi verificada a presença somente dos ossos e tecidos provenientes das roupas, pois a matéria orgânica (juntamente com a madeira do caixão, a serragem e maravalha) se degrada totalmente. Essas exumações são feitas geralmente para acondicionar os ossos e o restante das roupas num saco plástico e dar lugar para outro cadáver no mesmo jazigo.

\subsection{4- Efluentes gasosos}

Não há caldeira, fornalha ou qualquer outro dispositivo que gere efluentes gasosos. Como já dito no item anterior, os gases originados do processo de degradação biológica não ficam no jazigo e percolam pelos interstícios do solo, não acarretando pressurização do jazigo nem mau cheiro na área de entorno.

\subsection{5 - Efluentes sólidos}

Na Tabela 2 é exposto um quantitativo dos resíduos sólidos gerados no cemitério, assim como o seu destino final.

Tabela 2 - Resíduos produzidos mensalmente e sua destinação

\begin{tabular}{|c|c|c|}
\hline Resíduo & Quantidade/mês & Destino \\
\hline Coroas de ferro & $100 \mathrm{Kg}$ & Reciclagem \\
\hline Flores & $200 \mathrm{Kg}$ & Lixo comum ou Compostagem \\
\hline Cera das velas & $40 \mathrm{Kg}$ & Reciclagem \\
\hline Vasos Plásticos & $8 \mathrm{Kg}$ & Doação para APAE \\
\hline
\end{tabular}

Fonte: Administração do cemitério (2006). 


\begin{tabular}{|r|c|}
\hline GEOAMBIENTE ON-LINE & \\
Revista Eletrônica do Curso de Geografia do Campus Jataí - UFG & www.jatai.ufg.br/geografia \\
| Jataí-Go | N.10 | jan-jun/2008 | & IS5N 1679-9860 \\
\hline
\end{tabular}

\subsection{6 - Poços de monitoramento de água}

Foram construídos 5 poços (Figura 5) de observação no interior do cemitério, sendo 1 a montante e 4 a jusante da área de sepultamentos para monitoramento da superfície freática e da qualidade da água subterrânea do aqüífero freático.



Figura 5 - Início da construção dos poços

A perfuração foi executada pelo método rotativo direto, conforme demonstrado na Figura 8, sem injeção de água ou fluídos de perfuração, com diâmetro externo de $300 \mathrm{~mm}$ e diâmetro interno de $100 \mathrm{~mm}$. Os poços apresentam profundidade em torno de 3,50 $\mathrm{m}$ a 4,50 m (Tabela 3).

Tabela 3 - Especificações dos poços de monitoramento

\begin{tabular}{|c|c|c|c|c|c|c|}
\hline Poço & $\begin{array}{c}\text { Cota do } \\
\text { terreno } \\
(\mathbf{m})\end{array}$ & $\begin{array}{c}\text { Cota do } \\
\text { poço } \\
(\mathbf{m})\end{array}$ & $\begin{array}{c}\text { Profundidade } \\
(\mathbf{m})\end{array}$ & $\begin{array}{c}\text { Nível } \\
\text { d'água } \\
(\mathbf{m})\end{array}$ & $\begin{array}{c}\text { Diâmetro } \\
\text { externo } \\
(\mathbf{m m})\end{array}$ & $\begin{array}{c}\text { Diâmetro } \\
\text { interno } \\
(\mathbf{m m})\end{array}$ \\
\hline PM-01 & 687 & 686,96 & 4,5 & N.D & 300 & 100 \\
\hline PM-02 & 681 & 680,95 & 3,5 & N.D & 300 & 100 \\
\hline PM-03 & 668 & 667,95 & 3,5 & 3,0 & 300 & 100 \\
\hline PM-04 & 667 & 666,95 & 3,6 & 3,0 & 300 & 100 \\
\hline PM-05 & 666 & 665,95 & 3,5 & 3,0 & 300 & 100 \\
\hline
\end{tabular}

Fonte: Santos Filho, 2006 


\section{GEOAMBIENTE ON-LINE \\ Revista Eletrônica do Curso de Geografia do Campus Jataí - UFG www.jatai.ufg.br/geografia | Jataí-GO | N.10 | jan-jun/2008

Conforme a Tabela 3 observa se que nas partes mais altas do terreno o nível de água do lençol freático não foi encontrado, tendo-se a certeza de que no ponto 1 o nível está abaixo de 4,5 $\mathrm{m}$ de profundidade e no ponto 2 , com 3,5 $\mathrm{m}$ de profundidade, encontrou-se basaltos da formação Serra Geral. Nos outros três pontos, a superfície de água foi encontrada com 3,0 m de profundidade.

A locação dos poços obedeceu à disposição das covas (sepulturas) e a direção do fluxo de água do lençol hidrostático $(1,00-1,10 \mathrm{~m})$, o qual acompanha a superfície do terreno. Deve-se ressaltar que o lençol freático está suscetível a variações conforme as ocorrências pluviométricas.

Os poços (Figura 6) são constituídos dos seguintes materiais:

> Filtro de tubo ranhurado (de PVC soldável), com ranhuras variando entre 0,4 $\mathrm{mm}$ a 0,6 $\mathrm{mm}$ de abertura para permitir o fluxo de fluídos para o interior. A extremidade inferior do tubo é fechado com tampa soldável;

Pré-filtro, que é o espaço anular entre o filtro e a parede do furo escavado, o qual foi preenchido por pedra brita $\mathrm{n}^{\mathrm{o}} 01$ e areia lavada média (Figura 7);

> Selo de proteção, constituído por argamassa de cimento e areia para acabamento de forma a evitar contaminação por escoamento superficial;

Tampa estanque e chave para evitar o acesso de pessoas não autorizadas;

Câmara de calçada, com identificação apropriada ao nível do pavimento, conforme ilustrado na Figura 8.

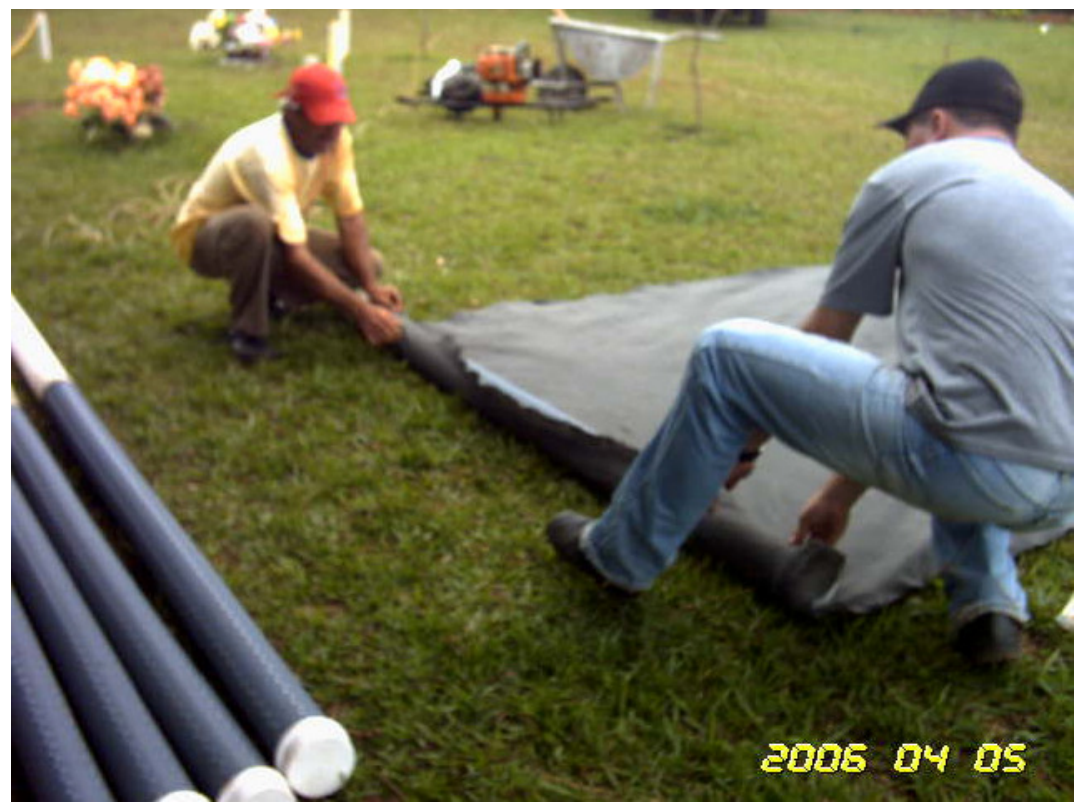

Figura 6 - Início da montagem do tubo de PVC com filtro 


\begin{tabular}{|r|c|}
\hline GEOAMBIENTE ON-LINE & \\
Revista Eletrônica do Curso de Geografia do Campus Jataí - UFG & www.jatai.ufg.br/geografia \\
| Jataí-GO | N.10 | jan-jun/2008 | & ISSN 1679-9860 \\
\hline
\end{tabular}

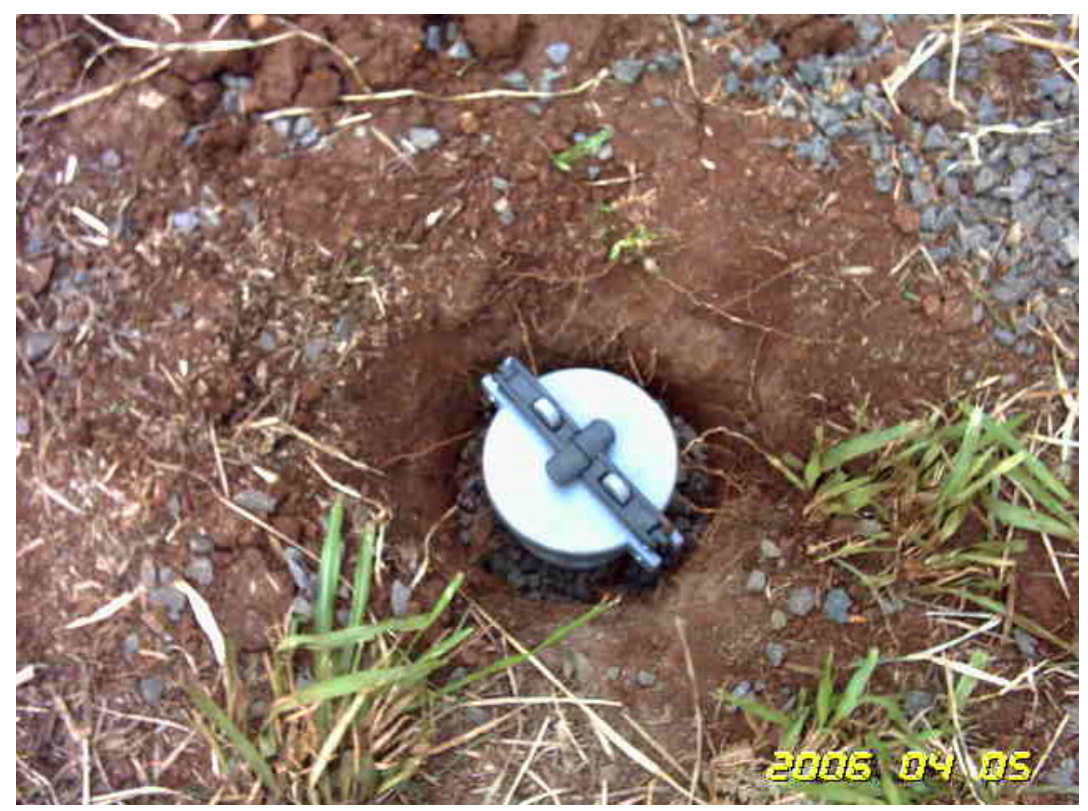

Figura 7 - Detalhe do poço com brita no seu entorno

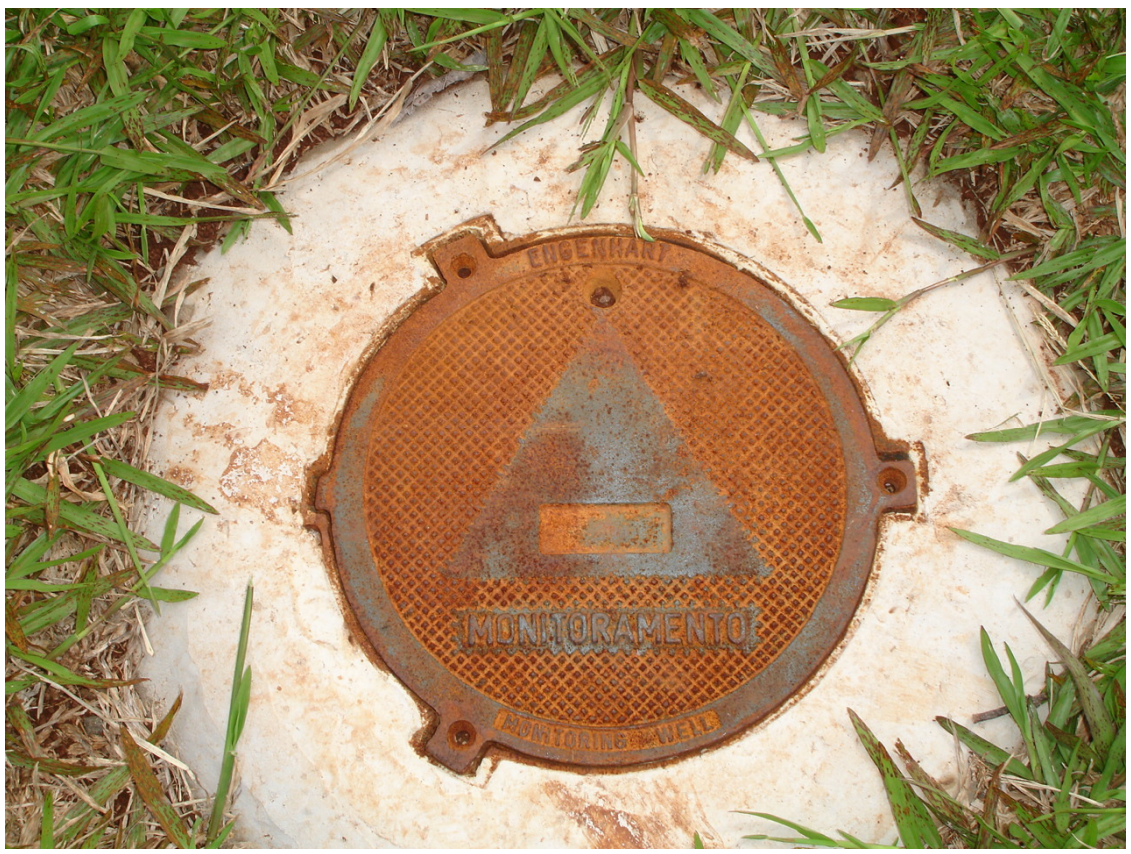

Figura 8 - Detalhe da tampa estanque de metal fixada a base de concreto junto ao solo

\section{Conclusões}






- Recomenda-se a implementação de recipientes para coleta das coroas de ferro, flores, ceras de vela e vasos plásticos devidamente indicados e em local coberto;

- Internamente, o cemitério deverá ser contornado por uma faixa com largura mínima de 5 (cinco) metros, destituída de qualquer tipo de pavimentação ou recobertura de alvenaria, destinada à implantação de uma cortina constituída por árvores e arbustos adequados. Esta faixa poderá ser destinada a edifícios, sistema viário ou logradouro de uso público, desde que não contrariem a legislação vigente;

- Caso sejam plantadas árvores no interior do cemitério, na chamada zona de enterramento ou sepultamento, estas deverão possuir raízes pivotantes a fim de evitar invasão de jazigos, destruição do piso e túmulos ou danos às redes de água, de esgoto e drenagem. As árvores não poderão ser muito altas devido a presença de um aeroporto na região circunvizinha;

- Conforme Resolução 019/04 - SEMA, para cemitérios implantados acima de 5 (cinco) anos, deverá haver amostragem anual das águas contidas nos poços de monitoramento para os seguintes parâmetros: sólidos totais dissolvidos, dureza total, $\mathrm{pH}$, cloreto, chumbo total, ferro total, fosfato total, nitrogênio amoniacal, nitrogênio nitrato, coliformes fecais, bactérias heterotróficas e mesófilas, salmonella sp, cálcio e magnésio.

- Os sepultamentos realizados na cota mais baixa do terreno (cujo nível do lençol freático está a 3,0 metros) deverão ter o nível inferior das sepulturas a uma distância mínima de 1,5 m (um metro e meio) abaixo da superfície.

\section{Referências bibliográficas}

ACKERMANN, L. A ameaça dos mortos. Revista Istoé, São Paulo, 2001. Disponível em: <http: //www.terra.com.br/istoe/Reportagens/cemiterio.htm>. Acesso em: 25 fev. 2006.

BARBOSA, M. C. \& COELHO, H. Impacto Ambiental dos Cemitérios Horizontais e sua Relação com o Controle Sanitário nas Áreas Urbanas. Disponível em $<\mathrm{http} / /$ :www.biossegurancahospitalar.com.br>. Acesso em: 22 fev. 2006.

BRASIL. Resolução $n$. 5, de 5 de agosto de 1993. Discorre sobre a necessidade de normas para o tratamento de resíduos sólidos oriundos de serviços de saúde, portos e aeroportos. Diário Oficial da República Federativa do Brasil, Brasília, DF, 31 ago. 1993. Disponível em: <http://www.mma.gov.br/port/conama/res/res93/res0593.html>. Acesso em: 23 fev. 2006. 


\section{GEOAMBIENTE ON-LINE \\ Revista Eletrônica do Curso de Geografia do Campus Jataí - UFG \\ www.jatai.ufg.br/geografia \\ | Jataí-GO | N.10 | jan-jun/2008

BRASIL. Resolução n. 237, de 19 de dezembro de 1997. Estabelece sobre a necessidade de licenciamento ambiental. Diário Oficial da República Federativa do Brasil, Brasília, DF, 19 dez. 1997. Disponível em: < http://www.mma.gov.br/port/conama/res/res97/res23797.html>. Acesso em: 23 fev. 2006.

BRASIL. Resolução n. 306, de 7 de dezembro de 2004. Dispõe sobre o Regulamento Técnico para o gerenciamento de resíduos de serviços de saúde. Diário Oficial da República Federativa do Brasil, Brasília, DF, 8 de dez. 2004. Disponível em: < http://www.luftech.com.br/legislacao/Resolucao\%20Anvisa\%20306.doc>. Acesso em: 25 de fev. 2006.

BRASIL. Resolução $n^{o}$ 335, de 3 de abril de 2003. Dispõe sobre o licenciamento ambiental de cemitérios. Diário Oficial da República Federativa do Brasil, Brasília, DF, 28 mai. 2006. Disponível em: < http://www.mma.gov.br/port/conama/res/res03/res33503.xml>. Acesso em: 25 fev. 2006.

BRASIL. Resolução n. 368, de 28 de março de 2006. Altera dispositivos da Resolução n ${ }^{\circ}$ 335, de 3 de abril de 2003, que dispõe sobre o licenciamento ambiental de cemitérios. Diário Oficial da República Federativa do Brasil, Brasília, DF, 29 dez. 2006. Disponível em: < http://www.mma.gov.br/port/conama/res/res06/res36806.xml>. Acesso em: 25 fev. 2006.

ESPINDULA, J. C. de. Caracterização bacteriológica e físico-química das águas do aqüífero freático do cemitério da várzea-Recife. 130f. Dissertação (Mestrado em Geociências) Universidade Federal de Pernambuco, Pernambuco, 2004.

LUZ, J. A. S. Plano de Manejo do Parque Municipal Irmão Cirilo. 100p. Projeto técnico, Francisco Beltrão: [s.n], 2006.

MATOS, Bolívar Antunes. Avaliação da ocorrência e do transporte de microorganismos no aqüífero freático do cemitério de Vila Nova Cachoeirinha, município de São Paulo. Tese de Doutoramento do Programa de Pós-graduação em Recursos Minerais e Hidrogeologia Instituto de Geociências da Universidade de São Paulo, São Paulo: [s.n], 2001.

MATOS, Bolívar Antunes; PACHECO, Alberto. Como os Cemitérios podem Contaminar as Águas Subterrâneas. Disponível em < http//:www.igc.usp.br/subsites/cemiterios/cemit.php $>$. Acesso em: 25 fev. 2006.

PARANÁ. Decreto n. 3320, de 12 de julho de 2004. Aprova os critérios, normas, procedimentos e conceitos aplicáveis ao SISLEG. Curitiba, PR, 12 jul. 2004. Disponível em: 


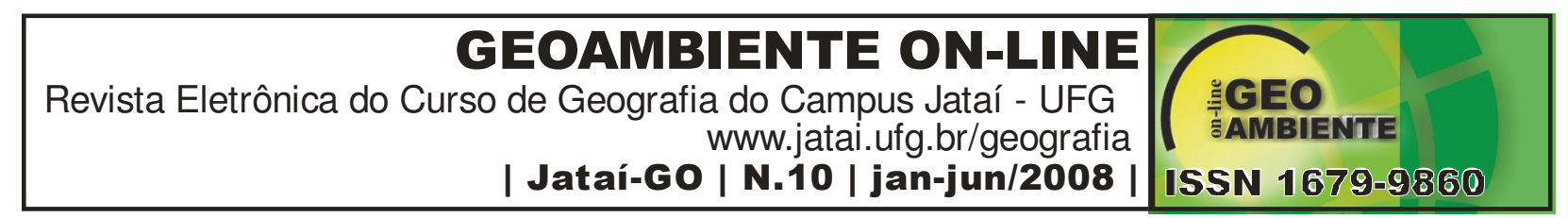

<http://celepar7cta.pr.gov.br/SEEG/sumulas.nsf/0/e0053d2f9?OpenDocument>. Acesso em: 23 fev. 2006.

PARANÁ. Resolução n. 019, de 04 de maio de 2004. Estabelece requisitos e condições técnicas para a implantação de cemitérios destinados ao sepultamento, no que tange à proteção e à preservação do ambiente, em particular do solo e das águas subterrâneas. Curitiba, PR, 04 mai. 2004. Disponível em: <http://www.pr.gov.br/meioambiente/pdf/res_019_04.pdf>. Acesso em: 24 fev. 2006.

SANTOS FILHO, J. F. dos. Poços de Monitoramento do lençol freático e estudo hidrogeoambiental. 2006. 19f. Laudo técnico, Francisco Beltrão: [s.n.], 2006. 